\title{
Insect galls from Serra dos Pireneus, GO, Brazil
}

\author{
Walter Santos de Araújo ${ }^{1,2,4}$, Benedito Baptista dos Santos ${ }^{2}$ \& Vera Lúcia Gomes-Klein ${ }^{3}$ \\ ${ }^{1}$ Departamento de Ecologia, Instituto de Pesquisas Ambientais e Ações Conservacionistas, \\ CEP 74025-020, Centro, Goiânia, GO, Brazil \\ ${ }^{2}$ Laboratório de Entomologia, Departamento de Ecologia, Instituto de Ciências Biológicas, \\ Universidade Federal de Goiás - UFG, Campus Samambaia, CP 131, CEP 74001-970, Goiânia, GO, Brazil \\ ${ }^{3}$ Laboratório de Morfologia e Taxonomia Vegetal, Departamento de Biologia Geral, \\ Instituto de Ciências Biológicas, Universidade Federal de Goiás - UFG, Campus Samambaia, \\ CP131, CEP 74001-970, Goiânia, GO, Brazil \\ ${ }^{4}$ Autor para correspondência: Walter Santos de Araújo, e-mail: walterbioaraujo@yahoo.com.br
}

ARAÚJO, W.S., SANTOS, B.B. \& GOMES-KLEIN, V.L. Insect galls from Serra dos Pireneus, GO, Brazil. Biota Neotrop. 11(2): http://www.biotaneotropica.org.br/v11n2/en/abstract?article+bn03211022011

\begin{abstract}
In this study we recorded the occurrence of insect galls, inductors and parasitoids in plants of several physiognomies of Brazilian Cerrado in the Serra dos Pireneus, Goiás State, Brazil. We found 62 morphotypes of gall on 28 botanical families, comprising 44 genera and 51 species. The plant families that showed the greatest richness of galls were Fabaceae, with eight morphotypes, and Styracaceae with six. Styrax pohlii (Styracaceae) was the host plant species with the greatest gall richness, featuring five morphotypes. Most of galls occurred on the leaves $(82.6 \%), 45.1 \%$ in vegetation of typical savanna and $35.4 \%$ in rocky savanna. Dipteran, Hemipteran and Lepidopteran galls were found, being $50.9 \%$ of them induced by Cecidomyiidae (Diptera). Several parasitoids were obtained, Eulophidae (Hymenoptera: Chalcidoidea) was the most representative group (occurring in approximately $40 \%$ of the galls). Nine species of plants were recorded for the first time in the Neotropical as host of gallers.
\end{abstract}

Keywords: Cecidomyiidae, gall makers, host plants, parasitoids.

ARAÚJO, W.S., SANTOS, B.B. \& GOMES-KLEIN, V.L. Galhas de insetos da Serra dos Pireneus, GO, Brasil. Biota Neotrop. 11(2): http://www.biotaneotropica.org.br/v11n2/pt/abstract?article+bn03211022011

Resumo: Neste estudo, registramos a ocorrência de galhas, galhadores e parasitóides em plantas de várias fitofisionomias de Cerrado na Serra dos Pireneus, Estado de Goiás, Brasil. Foram encontrados 62 morfotipos de galhas em 28 famílias botânicas, compreendendo 44 gêneros e 51 espécies. As famílias botânicas que apresentaram maior riqueza de galhas foram Fabaceae, com oito morfotipos e Styracaceae com seis. Styrax pohlii (Styracaceae) foi a espécie de planta hospedeira mais rica em galhas, apresentando cinco morfotipos. A maioria das galhas ocorreu nas folhas $(82,6 \%)$ e em fitofisionomias de cerrado típico $(45,1 \%)$ e cerrado rupestre $(35,4 \%)$. Galhas de Diptera, Hemiptera e Lepidoptera foram encontradas, sendo 50,9\% induzidas por Cecidomyiidae (Diptera). Vários parasitóides obtidos, dentre eles, Eulophidae (Hymenoptera: Chalcidoidea) foram foi o grupo mais representativo (ocorrendo em aproximadamente $40 \%$ das galhas). Nove espécies de plantas são registradas pela primeira vez na região Neotropical como hospedeiras de galhadores.

Palavras-chaves: Cecidomyiidae, insetos galhadores, plantas hospedeiras, parasitóides. 


\section{Introduction}

The gall formation on plants is characterized by abnormal growth of plant tissues by cell hypertrophy and hyperplasia (Mani 1964, Price 2005). These galls are the most sophisticated herbivore interactions of nature (Shorthouse et al. 2005). The gall-inducing insects have the ability to manipulate the development of plant tissue and promote its growth (Stone \& Schönrogge 2003) and the development of these structures has been an adaptive strategy of many insects for their food and even protection against predators (Mani 1964, Stone \& Schönrogge 2003).

Although they represent great benefits to insects, galls can cause severe damage to the host plant (Gallo et al. 1988). Usually, galling insects are associated with the conducting tissues drawing water and nutrients, causing deficiencies to the plant, compromising their development and reproduction (Butignol \& Pedrosa-Macedo 2003). In some crops, some gall-midges (Cecidomyiidae: Diptera) can cause economic damage, as Jatrophobia brasiliensis (Rubsaamen, 1907) that forms galls on the upper surface of leaves of cassava, deforming them and hindering the normal development of the plant and Contarinia sorghicola (Coquillett, 1898) whose larvae feed on the floral ovary preventing the development of grain sorghum, and the considerable damage, where the panicles are fine and there are no grains formed (Nakano et al. 1981).

The early works on galls in Brazil date to the beginning of last century with Tavares $(1906,1917)$. However, since the late 1980s a series of inventory of galls has been developed in the Southeast (Fernandes et al. 1988, Fernandes et al. 1997, Maia 2001, UrsoGuimarães et al. 2003, Maia \& Fernandes 2004, Oliveira \& Maia 2004, Maia et al. 2008, Carneiro et al. 2009, Bregonci et al. 2010), South (Dalbem \& Mendonça 2006), North (Julião et al. 2005), and Northeast (Fernandes et al. 2009) of the country. In the Midwest, specifically in the State of Goiás, ecological studies of galling (Araújo \& Santos 2008, Araújo \& Santos 2009a, b) and inventories of galls and host plants (Araújo et al. 2007, Santos et al. 2010) are more recent. In this paper, we report the morphotypes of galls, gall-inducing insects and host plants from Serra dos Pireneus, Goiás, Brazil.

\section{Material and Methods}

The study was conducted at Parque Estadual da Serra dos Pireneus (S $15^{\circ} 48^{\prime}$; W $48^{\circ} 52^{\prime}$ ) located in the municipalities of Pirenópolis, Corumbá de Goiás and Cocalzinho of Goiás, about $18 \mathrm{~km}$ of Pirenópolis, Midwest of Brazil (Figure 1). The park area covers 2833.26 ha and includes regions of typical savanna ("cerrado sensu stricto"), rocky savanna ("cerrado rupestre"), gallery forest ("mata de galleria") and stational semidecidual forest ("mata estacional semidecidual"). The climate according to Köppen's classification is Aw with a dry season (April to September) and a rainy season (October to March) well defined.

Quarterly expeditions were conducted for the study area between August 2006 and July 2008. Surveys were conducted in different vegetation physiognomies and all plants with galls were sampled. Fragments of organs attacked and also samples of plant reproductive materials were collected to obtain the gall-inducing insects and identification of the host plant, respectively. When possible, the identification of plant species was done on site.

The collected galls were taken to the Entomology Laboratory of the Universidade Federal de Goiás (UFG) and packed in plastic container with moistened paper. Observations were made daily until emergence of insects. As they emerged, the bugs were fixed in $70 \%$ alcohol for further identification. After that, we analyzed the external characteristics of galls, such as colour, pubescence, leaf surface (adaxial or abaxial leaf) and internal ones (number of chamber and dwellers). The insects were identified in orders and families, using entomological keys (Triplehorn \& Johnson 2005). The galling insects and parasitoids are fixed in $70 \%$ alcohol and deposited in the Entomology Laboratory of UFG.

The identification of the plants was made by comparison with the collections of UFG, herbarium, literature, as well as consultation with specialists. We followed the APG II classification system for all plant identifications (Souza \& Lorenzi 2005). The botanical material was cataloged and stored in the Laboratory of Morphology and Plant Taxonomy of UFG.

\section{Results}

We found 62 gall morphotypes, distributed on 28 botanical families comprising 44 genera and 51 species (Table 1). The plant families that showed the greatest richness of galls were Fabaceae, with eight morphotypes, Styracaceae with six, Malpighiaceae with five, Euphorbiaceae and Vochysiaceae with four, Melastomataceae, Myrtaceae and Sapotaceae with three morphotypes. The remaining families had one or two gall morphotypes each (Table 1).

Gall morphotypes and their characteristics are listed in Table 2. Styrax L. (Styracaceae) and Qualea Aubl. (Vochysiaceae) were the richest genera in number of gall morphotypes (six and four, respectively). Styrax pohlii A.DC. (Styracaceae) was the super host

Table 1. Correlation of gall morphotypes, insect taxa (insect gall inducers and parasitoids) and host plants per plant family in areas of Cerrado from Serra do Pireneus, Goiás, Brazil.

\begin{tabular}{|c|c|c|c|}
\hline $\begin{array}{c}\text { Botanical } \\
\text { family }\end{array}$ & $\begin{array}{c}\text { Number of } \\
\text { plant species }\end{array}$ & $\begin{array}{l}\text { Number of } \\
\text { insect taxa }\end{array}$ & $\begin{array}{c}\text { Number of gall } \\
\text { morphotypes }\end{array}$ \\
\hline Fabaceae & 6 & 3 & 8 \\
\hline Styracaceae & 2 & 2 & 6 \\
\hline Malpighiaceae & 5 & 3 & 5 \\
\hline Euphorbiaceae & 4 & 2 & 4 \\
\hline Vochysiaceae & 2 & 1 & 4 \\
\hline Melastomataceae & 3 & 4 & 3 \\
\hline Myrtaceae & 3 & 4 & 3 \\
\hline Sapotaceae & 2 & 1 & 3 \\
\hline Asteraceae & 2 & 2 & 2 \\
\hline Bignoniaceae & 2 & 1 & 2 \\
\hline Caryocaraceae & 1 & 2 & 2 \\
\hline Clusiaceae & 2 & 1 & 2 \\
\hline Dilleniaceae & 1 & 3 & 2 \\
\hline Malvaceae & 2 & 3 & 2 \\
\hline Anacardiaceae & 1 & 1 & 1 \\
\hline Annonaceae & 1 & 2 & 1 \\
\hline Apocynaceae & 1 & 1 & 1 \\
\hline Burseraceae & 1 & - & 1 \\
\hline Combretaceae & 1 & - & 1 \\
\hline Ebenaceae & 1 & 2 & 1 \\
\hline Erytroxylaceae & 1 & 1 & 1 \\
\hline Loranthaceae & 1 & 1 & 1 \\
\hline Ochnaceae & 1 & 1 & 1 \\
\hline Piperaceae & 1 & 2 & 1 \\
\hline Proteaceae & 1 & 1 & 1 \\
\hline Rubiaceae & 1 & 1 & 1 \\
\hline Sapindaceae & 1 & 1 & 1 \\
\hline Smilacaceae & 1 & 1 & 1 \\
\hline Total & 51 & 47 & 62 \\
\hline
\end{tabular}


Insect galls from Serra dos Pireneus, GO, Brazil

Table 2. Host plant characteristics (family, species and habit) and morphology of the galls collected in the typical savanna (TS), rocky savanna (RS), gallery forest (GF) and stational semidecidual forest (SF) in the Serra dos Pireneus, Goiás, Brazil.

\begin{tabular}{|c|c|c|c|c|c|c|c|}
\hline \multirow{2}{*}{$\begin{array}{c}\text { Host plant } \\
\text { Family and species }\end{array}$} & \multirow[t]{2}{*}{ Habit } & \multicolumn{5}{|c|}{ Morphology } & \multirow[t]{2}{*}{ Vegetation } \\
\hline & & Organ & Form & Color & Pubescence & Occurrence & \\
\hline $\begin{array}{l}\text { ANACARDIACEAE } \\
\text { Anacardium humile A.St.-Hil. }\end{array}$ & Shrub & Leaf & Conical & Green & Glabrous & Isolated & TS, RS \\
\hline $\begin{array}{l}\text { ANNONACEAE } \\
\text { Annona coriacea } \text { Mart. }\end{array}$ & Shrub & Leaf & Globoid & Green/Red & Glabrous & Isolated & TS \\
\hline $\begin{array}{l}\text { APOCYNACEAE } \\
\text { Aspidosperma tomentosum Mart. }\end{array}$ & Shrub & Leaf & Discoid & Yellow & Glabrous & Isolated & RS \\
\hline $\begin{array}{l}\text { ASTERACEAE } \\
\text { Asteraceae sp. } 1\end{array}$ & Shrub & Leaf & Globoid & Green & Hairy & Isolated & $\mathrm{TS}$ \\
\hline Asteraceae sp. 2 & Shrub & Leaf & Globoid & Green & Hairy & Isolated & TS \\
\hline $\begin{array}{l}\text { BIGNONIACEAE } \\
\text { Arrabidaea } \mathrm{sp} .\end{array}$ & Liana & Stem & Elipsoid & Green/White & Glabrous & Isolated & GF \\
\hline Tabebuia sp. & Shrub & Leaf & Conical & Green/Yellow & Hairy & Isolated & RS \\
\hline $\begin{array}{l}\text { BURSERACEAE } \\
\quad \text { Protium heptaphyllum March. }\end{array}$ & Tree & Leaf & Conical & Green/Yellow & Glabrous & Isolated & SF \\
\hline \multirow{2}{*}{$\begin{array}{l}\text { CARYOCARACEAE } \\
\text { Caryocar brasiliense Camb. }\end{array}$} & Tree & Leaf & Globoid & Green & Hairy & Aggregate & $\mathrm{TS}$ \\
\hline & & Leaf & Globoid & Yellow & Glabrous & Isolated & $\mathrm{TS}$ \\
\hline $\begin{array}{l}\text { CLUSICEAE } \\
\text { Calophylum brasiliensis Camb. }\end{array}$ & Tree & Leaf (adaxial) & Globoid & Green & Glabrous & Isolated & GF \\
\hline Clusia sp. & Shrub & Leaf (abaxial) & Amorphous & Red & Hairy & Isolated & TS \\
\hline $\begin{array}{l}\text { COMBRETACEAE } \\
\text { Terminalia argentea Mart. \& Zucc. }\end{array}$ & Tree & Leaf (abaxial) & Globoid & Brown & Hairy & Isolated & $\mathrm{TS}$ \\
\hline \multirow{2}{*}{$\begin{array}{l}\text { DILLENIACEAE } \\
\text { Davilla elliptica A.St.-Hil. }\end{array}$} & Shrub & Leaf & Discoid & Green & Hairy & Isolated & $\mathrm{TS}$ \\
\hline & & Stem & Elipsoid & Brown & Hairy & Aggregate & TS \\
\hline $\begin{array}{l}\text { EBENACEAE } \\
\text { Dyospirus burchellii D.C. }\end{array}$ & Shrub & Stem & Globoid & Green & Hairy & Isolated & $\mathrm{TS}$ \\
\hline $\begin{array}{l}\text { ERYTHROXYLACEAE } \\
\text { Erythroxylum suberosum A.St.-Hil. }\end{array}$ & Shrub & Vein & Globoid & Green & Hairy & Isolated & $\mathrm{RS}$ \\
\hline $\begin{array}{l}\text { EUPHORBIACEAE } \\
\text { Manihot } \text { sp. } 1\end{array}$ & Herb & Leaf & Globoid & Red & Glabrous & Isolated & $\mathrm{RS}$ \\
\hline Manihot sp. 2 & Herb & Leaf & Globoid & Brown & Glabrous & Isolated & RS \\
\hline Manihot sp. 3 & Herb & Leaf & Globoid & Red & Hairy & Isolated & $\mathrm{RS}$ \\
\hline Sebastiania sp. & Shrub & Petiole & Globoid & Green & Hairy & Isolated & RS \\
\hline $\begin{array}{l}\text { FABACEAE } \\
\text { Acosmium dasycarpum (Vogel) } \\
\text { Yakovlev }\end{array}$ & Shrub & Leaf & Discoid & Green & Glabrous & Isolated & $\mathrm{RS}$ \\
\hline Anadenanthera peregrina (L.) Spreng. & Tree & Leaf & Globoid & Red & Glabrous & Isolated & GF, SF \\
\hline \multirow[t]{3}{*}{ Andira paniculata Benth. } & Shrub & Leaf & Elipsoid & Green & Glabrous & Isolated & RS \\
\hline & & Leaf & Amorfa & Green & Glabrous & Isolated & RS \\
\hline & & Leaf & Discoid & Green & Glabrous & Isolated & $\mathrm{RS}$ \\
\hline Bauhinia ungulata L. & Tree & Vein & Globoid & Red & Hairy & Isolated & SF \\
\hline Bauhinia sp. & Shrub & Leaf (abaxial) & Discoid & Green & Glabrous & Isolated & $\mathrm{RS}$ \\
\hline Hymenaea stignocarpa Mart. ex Hayne & Tree & Leaf & Discoid & Green & Glabrous & Isolated & TS, RS \\
\hline $\begin{array}{l}\text { LORANTHACEAE } \\
\text { Struthanthus sp. }\end{array}$ & Epiphyte & Leaf & Discoid & Brown & Glabrous & Isolated & $\mathrm{TS}$ \\
\hline $\begin{array}{l}\text { MALPIGHIACEAE } \\
\text { Byrsonima pachyphylla Griseb. }\end{array}$ & Shrub & Leaf & Conical & Green & Glabrous & Isolated & $\mathrm{TS}$ \\
\hline $\begin{array}{l}\text { Byrsonima guilleminiana Brad. \& } \\
\text { Mark. }\end{array}$ & Shrub & Leaf & Discoid & Yellow & Glabrous & Isolated & TS \\
\hline
\end{tabular}


Table 2. Continued...

\begin{tabular}{|c|c|c|c|c|c|c|c|}
\hline \multirow{2}{*}{$\begin{array}{c}\text { Host plant } \\
\text { Family and species }\end{array}$} & \multirow[t]{2}{*}{ Habit } & \multicolumn{5}{|c|}{ Morphology } & \multirow[t]{2}{*}{ Vegetation } \\
\hline & & Organ & Form & Color & Pubescence & Occurrence & \\
\hline Byrsonima sp. & Shrub & Leaf & Conical & Yellow & Glabrous & Isolated & $\mathrm{TS}$ \\
\hline Malpighiaceae sp. 1 & Shrub & Leaf & Globoid & Green & Glabrous & Isolated & TS \\
\hline Pterandra pyroidea A. Juss. & Shrub & Leaf & Globoid & Green & Glabrous & Isolated & SF \\
\hline \multicolumn{8}{|l|}{ MALVACEAE } \\
\hline $\begin{array}{l}\text { Pseudobombax longiflorum (Mart. \& } \\
\text { Zucc.) A. Robyns }\end{array}$ & Tree & Leaf & Conical & Red & Glabrous & Isolated & $\mathrm{TS}$ \\
\hline Sida micrantha A.St.-Hil & Herb & $\begin{array}{l}\text { Leaf/Petiole/ } \\
\text { Stem }\end{array}$ & Globoid & Yellow & Hairy & Isolated & $\mathrm{TS}$ \\
\hline \multicolumn{8}{|l|}{ MELASTOMATACEAE } \\
\hline Macairea radula (Bonpl.) DC. & Shrub & Leaf/Stem & Globoid & Yellow/Red & Hairy & Isolated & $\mathrm{RS}$ \\
\hline Melastomataceae sp. & Shrub & Leaf & Globoid & Yellow & Hairy & Isolated & RS \\
\hline Miconia albicans (Sw.) Triana & Shrub & Leaf & Globoid & Yellow & Glabrous & Isolated & SF \\
\hline \multicolumn{8}{|l|}{ MYRTACEAE } \\
\hline Eugenia punicifolia (Kunth) DC. & Herb & Leaf & Elipsoid & Green & Hairy & Aggregate & GF \\
\hline Myrcia sp. & Tree & Leaf (abaxial) & Globoid & Brown & Glabrous & Isolated & GF \\
\hline $\begin{array}{l}\text { Psidium pohlianum O.Berg. } \\
\text { OCHNACEAE }\end{array}$ & Shrub & Leaf & Globoid & Green & Glabrous & Isolated & TS, RS \\
\hline $\begin{array}{l}\text { Ouratea hexasperma (A. St. Hil.) Baill. } \\
\text { PIPERACEAE }\end{array}$ & Shrub & Leaf & Discoid & Yellow & Glabrous & Isolated & $\mathrm{TS}$ \\
\hline \multicolumn{8}{|l|}{ PROTEACEAE } \\
\hline \multicolumn{8}{|l|}{ RUBIACEAE } \\
\hline \multicolumn{7}{|l|}{ SAPINDACEAE } & TS \\
\hline Serjania sp. & Liana & Vein & Elipsoid & Brown & Glabrous & Isolated & $\mathrm{SF}$ \\
\hline \multicolumn{8}{|l|}{ SAPOTACEAE } \\
\hline \multirow[t]{2}{*}{ Micropholis sp. } & Tree & Leaf & Globoid & Green & Glabrous & Isolated & GF \\
\hline & & Stem & Globoid & Brown & Glabrous & Isolated & GF \\
\hline $\begin{array}{l}\text { Pouteria ramiflora (Mart.) Radlk. } \\
\text { SMILACACEAE }\end{array}$ & Shrub & Stem & Elipsoid & Brown & Glabrous & Isolated & $\mathrm{RS}$ \\
\hline Smilax sp. & Shrub & Leaf & Globoid & Green & Glabrous & Isolated & $\mathrm{TS}$ \\
\hline \multicolumn{8}{|l|}{ STYRACACEAE } \\
\hline Styrax sp. & Shrub & Leaf & Globoid & Brown & Hairy & Isolated & $\mathrm{TS}$ \\
\hline \multirow[t]{5}{*}{ Styrax pohlii DC. } & Tree & Leaf & Elipsoid & Green & Glabrous & Isolated & SF \\
\hline & & Leaf & Discoid & Green/ Purple & Glabrous & Isolated & SF \\
\hline & & Leaf & Discoid & Brown & Glabrous & Isolated & $\mathrm{SF}$ \\
\hline & & Stem & Globoid & Brown & Glabrous & Isolated & $\mathrm{SF}$ \\
\hline & & Stem & Elipsoid & Brown & Glabrous & Isolated & $\mathrm{SF}$ \\
\hline \multicolumn{8}{|l|}{ VOCHYSIACEAE } \\
\hline Qualea grandiflora Mart. & Tree & Leaf & Discoid & Green/Brown & Glabrous & Isolated & TS, RS \\
\hline Qualea parviflora Mart. & Tree & Leaf & Globoid & Red & Hairy & Isolated & $\mathrm{TS}$ \\
\hline & & Leaf & Globoid & Green & Glabrous & Isolated & $\mathrm{TS}$ \\
\hline & & Leaf & Discoid & Green/Brown & Glabrous & Isolated & $\mathrm{TS}$ \\
\hline
\end{tabular}


plant species, featuring five morphotypes. Andira paniculata Benth. (Fabaceae) and Qualea parviflora Mart. (Vochysiaceae), had three morphotypes each and Davilla elliptica A.St.-Hill (Dilleniaceae), two. The remaining species had only one morphotype.

Most gall morphotypes were found in xeric environments, 28 occurred in typical savanna (45.1\%) and 22 in rocky savanna (35.4\%). In addition, there were 12 galls in stational semidecidual forest $(19.3 \%)$ and eight in the gallery forest (12.9\%) (Tables 2 and 3). The majority of the gall morphotypes was found $53.2 \%$ on shrubs, $33.8 \%$ on trees, $8.1 \%$ on herbs, $3.2 \%$ on lianas and $1.6 \%$ on epiphytes, as shown in Table 4.

Most galls occurred in the leaf surface $(82.6 \%)$. Stem galls $(11.2 \%)$ and less frequently vein galls (4.8\%) and petiole gall (1.6\%) were also found. All morphotypes occurred in only one plant organ, with the exception of galls on Sida micrantha A.St.-Hill. (Malvaceae) and Macairea radula (Bonpl.) DC. (Melastomataceae), which occurred in two organs (leaves and stems).

This is the first report of galls occurrence for the Neotropical region on the following species of host plants: Davilla elliptica A.St.-Hill. (Dilleniaceae), Andira paniculata Benth. (Fabaceae), Byrsonima pachyphylla Griseb. (Malpighiaceae), Byrsonima guilleminiana Brad. \& Mark. (Malpighiaceae), Pterandra pyroidea A.Juss. (Malpighiaceae), Pseudobombax longiflorum (Mart. \& Zucc.) A. Robyns (Malvaceae), Psidium pohlianum O.Brerg. (Myrtaceae), Pouteria ramiflora (Mart.) Radlk. (Sapotaceae) and Qualea grandiflora Mart. (Vochysiaceae).

Table 3. Correlation of gall morphotypes and vegetation physiognomy in the Serra dos Pireneus, Goiás, Brazil.

\begin{tabular}{lc}
\hline \multicolumn{1}{c}{ Vegetation physiognomy } & Number of gall morphotypes \\
\hline Typical savanna & $28(45,1 \%)$ \\
Rocky savanna & $22(35,4 \%)$ \\
Stational semidecidual forest & $12(19,3 \%)$ \\
Gallery forest & $08(12,9 \%)$
\end{tabular}

The total represents more than $100 \%$ because some morphotypes occurred in more than one vegetation type.
In this study we found gall-inducing insects belonging to Diptera (Cecidomyiidae), Hemiptera (Psyllidae) and Lepidoptera (Gelechiidae) (Table 5). The most common was Cecidomyiidae (Diptera), which induced galls on 26 plant species, representing $50.9 \%$ of the total. Galling of Lepidoptera and Hemiptera were also observed, being found in $9.8 \%$ and $5.8 \%$ of the plants, respectively.

Besides the gall makers, we obtained several parasitoids of five Hymenoptera families: Chalcididae, Encyrtidae, Eulophidae, Eupelmidae and Trichogrammatidae occurring in approximately $40 \%$ of galls (Table 6). Eulophidae was the most representative family (occurring in $19.6 \%$ of plants). In some species of plants, the parasitoids were found together with the galling (see Table 5). Already in $17.6 \%$ of plants were obtained only Hymenoptera, not observed any insect taxa galling (it is not known whether these Hymenoptera are parasitoids or galling agents.). Gall inducers or parasitoids were not obtained from $15.6 \%$ of the host plants (Table 6), possibly because the galls collected were already empty.

\section{Discussion}

Many inventories on the diversity of galls in the Cerrado indicate Fabaceae (Fernandes et al. 1997, Gonçalves-Alvim \& Fernandes 2001, Maia \& Fernandes 2004, Urso-Guimarães \& Scareli-Santos 2006, Santos et al. 2010) and Asteraceae (Fernandes et al. 1996, Carneiro et al. 2009) as the most important host families. Similarly, in this study, Fabaceae was the most representative family, especially in the areas of Cerrado, both in savanna and in forest

Table 4. Correlation of gall morphotypes according to the habit of the host plant in the Serra dos Pireneus, Goiás, Brazil.

\begin{tabular}{lc}
\hline Habit & Number of gall morphotypes \\
\hline Shrub & $33(53,2 \%)$ \\
Tree & $21(33,8 \%)$ \\
Herb & $5(8,1 \%)$ \\
Liana & $2(3,2 \%)$ \\
Epiphyte & $1(1,6 \%)$ \\
\hline
\end{tabular}

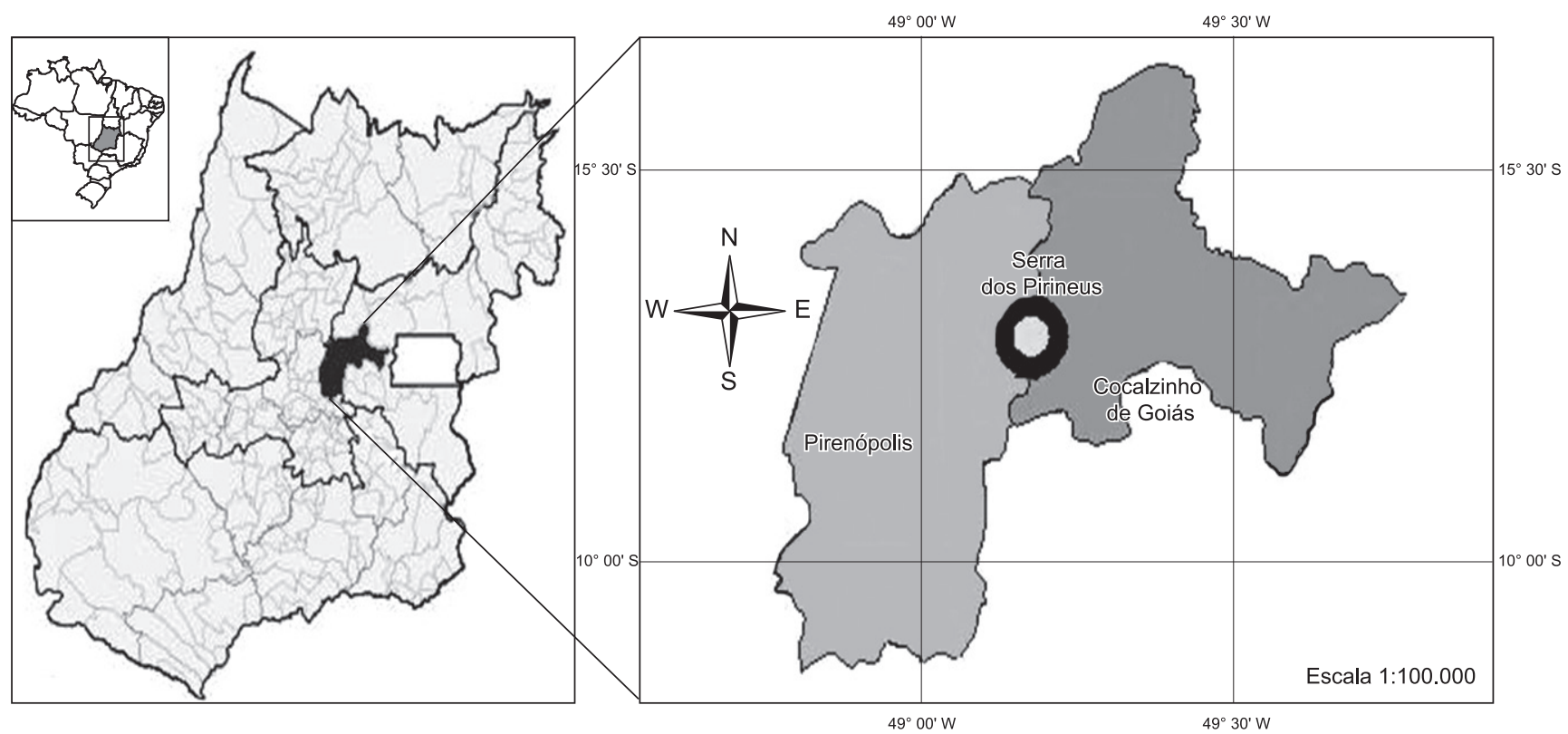

Figure 1. Localization of State Park of the Serra dos Pireneus in the municipalities of Pirenópolis, Corumbá de Goiás and Cocalzinho of Goiás, Midwest, Brazil. 
Araújo, W.S. et al.

Table 5. Occurrence of gall-inducing insects and parasitoids in observed plant species in areas of Cerrado from Serra dos Pireneus, Goiás, Brazil.

\begin{tabular}{|c|c|c|c|}
\hline \multicolumn{2}{|r|}{ Host plant } & \multirow{2}{*}{$\begin{array}{l}\text { Gall-inducing } \\
\text { insects }\end{array}$} & \multirow{2}{*}{$\begin{array}{l}\text { Parasitoids } \\
\text { insects }\end{array}$} \\
\hline Family & Species & & \\
\hline ANACARDIACEAE & Anacardium humile A.St.-Hil. & Cecidomyiidae & - \\
\hline ANNONACEAE & Annona coriacea Mart. & Cecidomyiidae & Eulophidae \\
\hline APOCYNACEAE & Aspidosperma tomentosum Mart. & Hemiptera & - \\
\hline \multirow[t]{2}{*}{ ASTERACEAE } & Asteraceae sp. 1 & Cecidomyiidae & - \\
\hline & Asteraceae sp. 2 & Cecidomyiidae & Encyrtidae \\
\hline \multirow[t]{2}{*}{ BIGNONIACEAE } & Arrabidaea sp. & Cecidomyiidae & - \\
\hline & Tabebuia sp. & Cecidomyiidae & - \\
\hline BURSERACEAE & Protium heptaphyllum March. & Indeterminate & - \\
\hline CARYOCARACEAE & Caryocar brasiliense Camb. & Cecidomyiidae & - \\
\hline \multirow[t]{2}{*}{ CLUSIACEAE } & Calophylum brasiliensis Camb. & Indeterminate & - \\
\hline & Clusia sp. & Cecidomyiidae & - \\
\hline COMBRETACEAE & Terminalia argentea Mart. \& Zucc. & Indeterminate & - \\
\hline \multirow[t]{2}{*}{ DILLENIACEAE } & Davilla elliptica A.St.-Hil. & Cecidomyiidae & Eulophidae \\
\hline & & Lepidoptera & - \\
\hline EBENACEAE & Dyospirus burchellii D.C. & Lepidoptera & Hymenoptera \\
\hline ERYTROXYLACEAE & Erythroxylum suberosum A.St.-Hil. & Cecidomyiidae & - \\
\hline \multirow[t]{4}{*}{ EUPHORBIACEAE } & Manihot sp. 1 & Cecidomyiidae & - \\
\hline & Manihot sp. 2 & Indeterminate & Eulophidae \\
\hline & Manihot sp. 3 & Cecidomyiidae & - \\
\hline & Sebastiania sp. & Cecidomyiidae & Eulophidae \\
\hline \multirow[t]{6}{*}{ FABACEAE } & Acosmium dasycarpum (Vogel) Yakovlev & Cecidomyiidae & - \\
\hline & Anadenathera peregrina (L.) Spreng. & Indeterminate & - \\
\hline & Andira paniculata Benth. & Cecidomyiidae & Encyrtidae \\
\hline & Bauhinia ungulata $\mathrm{L}$. & Cecidomyiidae & - \\
\hline & Bauhinia sp. & Indeterminate & Eulophidae \\
\hline & Hymenaea stygnocarpa (Mart) ex Hayne. & Cecidomyiidae & - \\
\hline LORANTHACEAE & Struthanthus sp. & Indeterminate & Hymenoptera \\
\hline \multirow[t]{5}{*}{ MALPIGHIACEAE } & Byrsonima pachyphylla (Sw.) DC & Cecidomyiidae & - \\
\hline & Byrsonima guilleminiana Brad.\& Mark. & Indeterminate & - \\
\hline & Byrsonima sp. & Cecidomyiidae & Trichogrammatidae \\
\hline & Malpighiaceae sp. 1 & Cecidomyiidae & Eulophidae \\
\hline & Pterandra pyroidea A. Juss. & Indeterminate & - \\
\hline \multirow[t]{2}{*}{ MALVACEAE } & Pseudobombax longiflorum (Mart. \& Zucc.) A. Robyns & Lepidoptera & Hymenoptera \\
\hline & Sida micrantha A.St.-Hil & Cecidomyiidae & Hymenoptera \\
\hline \multirow[t]{3}{*}{ MELASTOMATACEAE } & Macairea radula (Bonpl.) DC. & Gelechiidae & Chalcididae \\
\hline & Melastomataceae sp. & - & Hymenoptera \\
\hline & Miconia albicans (Sw.) Triana & Cecidomyiidae & - \\
\hline \multirow[t]{3}{*}{ MYRTACEAE } & Eugenia punicifolia (Kunth) DC. & - & Hymenoptera \\
\hline & Myrcia sp. & Cecidomyiidae & Hymenoptera \\
\hline & Psidium pohlianum O.Berg. & Psyllidae & Eulophidae \\
\hline OCHNACEAE & Ouratea hexasperma (A. St. Hil.) Baill. & Lepidoptera & - \\
\hline PIPERACEAE & Piper arboreum Aubl. & - & Eulophidae \\
\hline PROTEACEAE & Roupala montana Aubl. & Psyllidae & - \\
\hline RUBIACEAE & Palicourea rigida Kunt & - & - \\
\hline SAPINDACEAE & Serjania sp. & Cecidomyiidae & - \\
\hline \multirow[t]{2}{*}{ SAPOTACEAE } & Micropholis sp. & - & - \\
\hline & Pouteria ramiflora (Mart.) Radlk. & Cecidomyiidae & - \\
\hline SMILACACEAE & Smilax sp. & - & - \\
\hline \multirow[t]{2}{*}{ STYRACACEAE } & Styrax sp. & - & Eupelmidae \\
\hline & Styrax pohlii DC. & Cecidomyiidae & - \\
\hline \multirow[t]{2}{*}{ VOCHYSIACEAE } & Qualea grandiflora Mart. & - & Eulophidae \\
\hline & Qualea parviflora Mart. & - & Eulophidae \\
\hline
\end{tabular}


Table 6. Correlation of insect orders and number of host plant species in the Serra dos Pireneus, Goiás, Brazil.

\begin{tabular}{lc}
\hline \multicolumn{1}{c}{ Insect order } & Number of host plant species \\
\hline Diptera (Cecidomyiidae) & $22(50,9 \%)$ \\
Lepidoptera & $5(9,8 \%)$ \\
Hemiptera & $3(5,8 \%)$ \\
Hymenoptera (Eulophidae) & $10(19,6 \%)$ \\
Hymenoptera (others) & $12(23,5 \%)$ \\
Unknown & $8(15,6 \%)$ \\
\hline
\end{tabular}

The total represents more than $100 \%$ because in some plants there is more than one taxon of insect.

(Mendonça et al. 1998, Silva-Júnior et al. 2001). Asteraceae, despite being the second largest family in number of species of the Cerrado (Mendonça et al. 1998), was ninth in gall diversity. This family seems to be quite representative of the diversity of galls in Southern (Mendonça 2007) and Southeast (Carneiro et al. 2009) Brazil.

Styrax and Qualea were the plant genera with the highest gall diversity in this study. At lower taxonomic levels, there may be a large concentration of galls in some taxa, these being known as super-hosts (Veldtman \& McGeoch 2003). According to Mendonça (2007), there are both super-hosts species and genera of plants, presenting such a wealth and abundance of galls morphotypes. This pattern was observed in this study, where the genus Styrax and specie Styrax pohlii, hosted respectively six and five gall types. Other super-host genera listed for Brazil and the Neotropical region are: Baccharis (Fernandes et al. 1996), Copaifera (Oliveira et al. 2008), Eugenia (Maia 2001), Miconia (Maia \& Fernandes 2004), Mikania (Mendonça 2007) and Myrcia (Maia et al. 2008).

Most galls of the Serra dos Pireneus were found in the vegetation of savanna and rocky savanna. The preference of galling in xeric environments can be explained by the hypothesis of nutritional stress, as described by Fernandes \& Price (1988). According to these authors, the galling richness is directly related to the nutritional stress of the environment. This is due to the large investment of plants in nutritionally stressed environments, lipids storage, carbohydrates and low in protein production. Under these conditions the plants are more sclerophyllous, with coriaceous leaves and stems, high hairiness, which reduces the probability of abscission. Thus, the plants become large food reserves and also give shelter and protection for insects, a fact responsible for the evolutionary success of gall-inducing insects (Fernandes et al. 1996, Allain et al. 1998, Gonçalves-Alvim $\&$ Fernandes 2001).

Testing the hypothesis of nutritional stress in the Serra dos Pireneus, Araújo \& Santos (2008) compared the richness of galling between xeric (typical savanna) and mesic (stational semidecidual forest) environments, but no significant differences were found between these two vegetation types. They found an average of 19.7 morphotypes per sample in the savanna and 19.2 in the stational semidecidual forest. According to the authors, the structural complexity of forest formation increases the diversity of this environment, making it equivalent in richness to the xeric environment. The authors also point to the importance of seasonality for the distribution of galling site, and in the dry season peak abundance of these insects.

Most galls were recorded in leaves (82.6\%), a pattern observed in most studies (Urso-Guimarães et al. 2006, Maia et al. 2008, Santos et al. 2010). In the Serra dos Pireneus, galls were more frequent in shrubs $(53.2 \%)$ than in trees $(33.8 \%)$, in accordance with the results of Oliveira \& Maia (2005) for areas of restinga. Much of the dominant vegetation in the Cerrado consists of shrubs, like in restingas, which may have influenced this pattern.

According to Maia et al. (2008), in the Neotropics, six orders of insects have gall inducing representatives: Diptera, Lepidoptera, Hymenoptera, Coleoptera, Hemiptera and Thysanoptera. Among these, there is a significant dominance of galls induced by Diptera, with registration of over a thousand morphotypes, mainly driven by Cecidomyiidae.

Cecidomyiidae, which was the most important galling group in Serra dos Pireneus, is a diversified family of basal Diptera. The Neotropical Cecidomyiidae fauna is poorly known and includes about 500 species in 170 genera (Gagné 1994, Gagné 2010). There are 159 species placed in 75 genera recorded for Brazil, 95 of these species and 47 of the genera occur in the State of Rio de Janeiro, representing $60 \%$ of the total for Brazil (Maia 2005).

We observed a high infestation of parasitoid insects in the galls studied (approximately 40\%). The micro-hymenoptera parasitoids are the most important natural enemies of gall-inducing insects, especially Cecidomyiidae (Maia \& Azevedo 2009). In the restingas on the coast of Brazil the rate of parasitism can reach $60 \%$ of the galls (Maia 2001, Maia et al. 2008). Maia \& Monteiro (1999) recorded 30 species of parasitoids in only three species of Bruggmannia (Cecidomyiidae) that galls Guapira opposita (Nyctaginaceae) in Restinga da Barra de Maricá, RJ. Micro-hymenoptera are also very common gall in the Brazilian cerrado. For example, Urso-Guimarães et al. (2003) found parasitoids of the families Braconidae, Eulophidae, Eurytomidae, Pteromalidae and Torymidae in a savanna of Delfinópolis, MG. On the other hand, Maia \& Fernandes (2004) recorded the parasitoids occurrence to be almost $35 \%$ of the gall morphotypes from Serra de São José, MG.

The number of gall-inducing insects species obtained in this study (62) is intermediate when compared to other studies. On one hand Carneiro et al. (2009) recorded 241 gall species in the rocky field of Cadeia do Espinhaço, MG. Maia \& Fernandes (2004) in a similar study of the Serra de São José, Brazil, recorded 137 gall morphotypes. On the other hand, Urso-Guimarães \& Scareli-Santos (2006), found 36 species in the Pé-de-Gigante, SP. In an area of savanna and forest in Belo Horizonte, MG, Fernandes et al. (1988) recorded 37 gall types. In another study, Urso-Guimarães et al. (2003) recorded only 22 morphotypes in areas of savanna, gallery forest and rocky field in Delfinópolis, MG. Factors such as richness and composition of host plants (Oyama et al. 2003), habitat type (Gonçalves-Alvim \& Fernandes 2001) and environmental conditions (Fernandes \& Price 1988) may influence patterns of local and regional distribution of these insects.

Gall studies in Brazil have been growing in recent years (Moreira 2006). Gall inventories are relatively common in Brazil, mainly in the Cerrado (Fernandes et al. 1997, Urso-Guimarães et al. 2003, Maia \& Fernandes 2004, Urso-Guimarães \& Scareli-Santos 2006, Santos et al. 2010) and in the Atlantic Forest (Maia 2001, Oliveira \& Maia 2005, Maia et al. 2008, Fernandes et al. 2009, Bregonci et al. 2010). In this context, several galls and gall-inducing insects have been described and new host plants are being recorded. Nevertheless, the vast majority of studies are concentrated in the Southeast region, whereas studies are still incomplete in the remaining regions of Brazil. The new records presented in this work indicates the importance of this type of study to inventory the diversity present in regions not sampled, such as the Cerrado of Central Brazil. 


\section{Acknowledgements}

The authors are thankful to V. C. Maia, A. F. N. Gonzaga and four anonymous reviewers for reviewing the manuscript; to H. D. Ferreira for host plants identification; to trainees of Entomology Laboratory and Laboratory of Morphology and Plant Taxonomy of UFG for help in the field and laboratory; to PRPPG-UFG for the grant to the first author, and the Instituto de Ciências Biológicas of UFG for the logistical support.

\section{References}

ALLAIN, L.R., LARA, A.C.F., FERNANDES, G.W. \& MARQUES, E.S.A. 1998. Leaf tannin concentration, toughness and sclerophylly in some typical woody species of the savannas of Southeastern Brazil. Bios 6(6):7-15

ARAÚJO, W.S. \& SANTOS, B.B. 2008. Efeitos do habitat e da sazonalidade na distribuição de insetos galhadores na Serra dos Pireneus, Goiás, Brasil. Rev. Biol. Neotr. 5:33-39.

ARAÚJO, W.S. \& SANTOS, B.B. 2009a. Efeitos da sazonalidade e do tamanho da planta hospedeira na abundância de galhas de Cecidomyiidae (Diptera) em Piper arboreum (Piperaceae). Rev. Bras. Ent. 53(2):300-303.

ARAÚJO, W.S. \& SANTOS, B.B. 2009b. Complexidade estrutural e diversidade de insetos galhadores em Styrax pohlii Fritsch (Styracaceae). Biosci. J. 25(3):181-184.

ARAÚJO, W.S., SANTOS, B.B., FERREIRA, H.D. \& LOUSA, T.C. 2007. Ocorrência de galhas entomógenas na vegetação do campus da UFG em Goiânia, Goiás. Rev. Bras. Bioc. 5(supl.1):57-59.

BREGONCI, J.M., POLYCARPO, P.V. \& MAIA, V.C. 2010. Galhas de insetos do Parque Estadual Paulo César Vinha (Guarapari, ES, Brasil). Biota Neotrop. 10(1): http://www.biotaneotropica.org.br/v10n1/pt/abstr act?inventory+bn01410012010 (último acesso em 29/09/2010).

BUTIGNOL, C.A. \& PEDROSA-MACEDO, J.H. 2003. Biologia de Neotrioza tavaresi Crawford, 1925 (Hemiptera, Psyllidae), galhador da Leaf do araçazeiro (Psidium cattleianum). Rev. Bras. Ent. 47(1):1-7.

CARNEIRO, M.A., BORGES, R.A.X., ARAÚJO, A.P.A \& FERNANDES, G.W. 2009. Insetos indutores de galhas da porção sul da Cadeia do Espinhaço, Minas Gerais, Brasil. Rev. Bras. Ent. 53(4):570-592. http:// dx.doi.org/10.1590/S0085-56262009000400007

DALBEM, R.V.\& MENDONCA, M.S. 2006. Diversity of Galling Arthropods and Host Plants in a Subtropical Forest of Porto Alegre, Southern Brazil. Neotr. Entomol. 35(5):616-624. PMid:17144132. http://dx.doi. org/10.1590/S1519-566X2006000500007

FERNANDES, G.W., ARAÚJO, R.C., ARAÚJO, S.C., LOMBARDI, J.A., PAULA, A.S., LOYOLA, R. \& CORNELISSEN, T.G. 1997. Insect-galls from savanna and rocky fields of the Jequitinhonha valley, Minas Gerais, Brazil. Naturalia. 22(2):221-244.

FERNANDES, G.W., CARNEIRO, M.A.A., LARA, A.C.F., ALLAIN, L.A., ANDRADE, G.I., JULIÃO, G., REIS, T.C. \& SILVA, I.M. 1996. Galling insects on neotropical species of Baccharis (Asteraceae). Trop. Zool. 9(2):315-332.

FERNANDES, G.W. \& PRICE, P.W. 1988. Biogeographical gradients in galling species richness: tests of hypotheses. Oecologia. 76:161-167. http://dx.doi.org/10.1007/BF00379948

FERNANDES, G.W., TAMEIRÃO-NETO, E. \& MARTINS, R.P. 1988. Ocorrência e caracterização de galhas entomógenas na vegetação do Campus Pampulha da Universidade Federal de Minas Gerais. Revi. Bras. Zoo. 5(1):11-29. http://dx.doi.org/10.1590/S0101-81751988000100002

FERNANDES, S.P.C., CASTELO-BRANCO, B.P., ALBUQUERQUE, F.A., FERREIRA, A.L.N., BRITO-RAMOS, A.B., BRAGA, D.V.V. \& ALMEIDA-CORTEZ, J. 2009. Galhas entomógenas em um fragmento urbano de Mata Atlântica no centro de endemismo de Pernambuco. Rev. Bras. Bioc. 7(3):240-244.

GAGNÉ, R.J. 1994. The Gall Midges of the Neotropical Region. Cornell University Press, Ithaca, New York.
GALLO, D., NAKANO, O., SILVEIRA NETO, S., CARVALHO, R.P.L., BATISTA, G.C., BERTI FILHO, E., PARRA, J.R.P., ZUCCHI, R.A., ALVES, S.B. \& VENDRAMIN, J.D. 1988. Manual de entomologia agrícola. Ed. Agron. Ceres Ltda., São Paulo.

GONÇALVES-ALVIM, S.J. \& FERNANDES, G.W. 2001. Biodiversity of galling insects: historical, community and habitat effects in four neotropical savannas. Biodivers. Conserv. 10(1):79-98. http://dx.doi. org/10.1023/A:1016602213305

JULIÃO, G.R., VENTICINQUE, E.M. \& FERNANDES, G.W. 2005. Richness and abundance of gall-forming insects in the Mamirauá Várzea, a flooded Amazonian forest. Rev. Uakari 1(1):39-42.

MAIA, V.C. 2001. The gall midges (Diptera, Cecidomyiidae) from three restingas of Rio de Janeiro State, Brazil. Rev. Bras. Zoo. 18(2):583-629. http://dx.doi.org/10.1590/S0101-81752001000200028

MAIA, V.C. 2005. Catálogo dos Cecidomyiidae (Diptera) do estado do Rio de Janeiro. Biota Neotrop. 5(2): http://www.biotaneotropica.org.br/v5n2/ pt/abstract?inventory+BN00805022005 (último acesso em 29/09/2010).

MAIA, V.C. \& AZEVEDO, M.A.P. 2009. Micro-himenópteros associados com galhas de Cecidomyiidae (Diptera) em Restingas do Estado do Rio de Janeiro (Brasil). Biota Neotrop. 9(2): http://www.biotaneotropica.org.br/ v9n2/en/abstract?article+bn02809022009 (último acesso em 29/09/2010).

MAIA, V.C. \& FERNANDES, G.W. 2004. Insect galls from Serra de São José (Tiradentes, MG, Brazil). Braz. J. Biol. 6(3A):423-445. http://dx.doi. org/10.1590/S1519-69842004000300007

MAIA, V.C. \& MONTEIRO, R.F. 1999. Espécies cecidógenas (Diptera, Cecidomyiidae) e parasitóides (Hymenoptera) associadas a Guapira opposita (Vell.) Reitz. (Nyctaginaceae) na Restinga da Barra de Maricá, Rio de Janeiro. Rev. Bras. Zoo. 16(2):483-487. http://dx.doi. org/10.1590/S0101-81751999000200013

MAIA, V.C., MAGENTA, M.A.G. \& MARTINS, S.E. 2008. Ocorrência e caracterização de galhas de insetos em áreas de restinga de Bertioga (São Paulo, Brasil). Biota Neotrop. 8(1):http://www.biotaneotropica. org.br/v8n1/en/abstract?inventory+bn02408012008 (último acesso em 29/09/2010).

MANI, M. S. 1964. Ecology of plant galls. Dr. W. Junk, The Hague.

MENDONÇA, R.C., FELFILI, J.M., WALTER, B.M.T., SILVA-JÚNIOR, M.C., REZENDE, A.B., FILGUEIRAS, T.S. \& NOGUEIRA, P.E. 1998. Flora Vascular do Cerrado. In Cerrado: ambiente e flora (S.M. Sano \& S.P. Almeida, eds). EMBRAPA - CPAC, Planaltina, p.289-556.

MENDONÇA, M.S. 2007. Plant diversity and galling arthropod diversity - searching for taxonomic patterns in an animal-plant interaction in the Neotropics. Bol. Soc. Arg. Bot. 42(3-4):347-357.

MOREIRA, G.R.P. 2006. Galhas entomógenas no Brasil: oportunidade de estudo sobre interação inseto-planta. In Os avanços da botânica no século XXI (J.E.A. Mariath \& R.P. Santos, orgs.). Congresso Nacional de Botânica, Gramado, p.532-537.

NAKANO, O., SILVEIRA NETO, S. \& ZUCCHI, R.A. 1981. Entomologia econômica. ESALQ-USP, Piracicaba.

OLIVEIRA, D.C., DRUMMOND, M.M., SOARES, G.L.G. \& ISAIAS, R.M.S. 2008. Potencialidades morfogênicas de Copaifera langsdorffii Desf. (Fabaceae): super-hospedeira de herbívoros galhadores. Rev. Biol. Neotr. 5(1):31-39.

OLIVEIRA, J.C. \& MAIA, V.C. 2005. Ocorrência e caracterização de galhas de insetos na restinga de Grumari (Rio de Janeiro, RJ, Brasil). Arq. Museu Nac. 63(4):669-675.

OYAMA, K., PÉREZ-PÉREZ, M.A., CUEVAS-REYES, P. \& LUNAREYES, L. 2003. Regional and local species richness of gall-inducing insects in two tropical rain forests in Mexico. J. Trop. Ecol. 19(5):595-598. http://dx.doi.org/10.1017/S0266467403003651

PRICE, P.W. 2005. Adaptative radiation of gall-inducing insects. Basic Appl. Ecol. 6(5):413-421. http://dx.doi.org/10.1016/j.baae.2005.07.002 
SANTOS, B.B., FERREIRA, H.D. \& ARAÚJO, W.S. 2010. Ocorrência caracterização de galhas em uma área de floresta estacional semidecídua em Goiânia, Goiás. Acta Bot. Bras. 24(1):217-223.

SHORTHOUSE, J.D., WOOL, D. \& RAMAN, A. 2005. Gall-inducing insects - Nature's most sophisticated herbivores. Basic App. Ecol. 6(5):407-411.

SILVA-JÚNIOR, M.C., FELFILI, J.M., WALTER, B.M.T., NOGUEIRA, P.E., REZENDE, A.V., MORAIS, R. DE O. \& NÓBREGA, M.G.G. 2001. Análise da flora arbórea de Matas de Galeria no Distrito Federal: 21 levantamentos. In Cerrado: caracterização e recuperação de matas de galeria (J.F. Ribeiro, C.E.L. Fonseca \& J.C. Sousa-Silva, eds.). Embrapa Cerrados, Brasília, p.143-191.

SOUZA, V.C. \& LORENZI, H. 2005. Botânica Sistemática: Guia ilustrado para identificação das famílias de Angiospermas da flora brasileira, baseado em APG II. Editora Plantarum, Nova Odessa, São Paulo.

STONE, G.N. \& SCHÖNROGGE, K. 2003. The adaptive significance of insect gall morphology. TREE 18(10):512-522. http://dx.doi.org/10.1016/ S0169-5347(03)00247-7

TAVARES, J.S. 1906. Descripção de uma Cecidomyia nova do Brasil, pertencente a um gênero novo. Brotéria. 5:81-84.
TAVARES, J.S. 1917. Cecídias brasileiras que se criam em plantas das Famílias Compositae, Rubiaceae, Tiliaceae, Lythraceae e Artocarpaceae. Brotéria. 15:113-181.

TRIPLEHORN, C.A. \& JOHNSON, N.F. 2005. Borror and Delong's Introduction to the Study of Insects. Thomson Brooks/Cole, New York.

URSO-GUIMARÃES, M.V., SCARELI-SANTOS, C. \& BONIFÁCIOSILVA, A.C. 2003. Occurrence and characterization of entomogen galls in plants from natural vegetation areas in Delfinópolis, MG, Brazil. Braz. J. Biol. 63(4):705-715

URSO-GUIMARÃES, M.V. \& SCARELI-SANTOS, C. 2006. Galls and gall makers in plants from Pé-de-Gigante Cerrado Reserve, Santa Rita do Passa Quatro, SP, Brazil. Braz. J. Biol. 66(1B):357-369.

GAGNÉ, R.J. 2010. Update for a catalog of the Cecidomyiidae (Diptera) of the world. Digital version 1.

VELDTMAN, R. \& McGEOCH, M.A. 2003. Gall-forming insect species richness along a non-scleromorphic vegetation rainfall gradient in South Africa: the importance of plant community composition. Austral Ecol. 28(1):1-13. http://dx.doi.org/10.1046/j.1442-9993.2003.01234.x

Recebido em 22/10/2010

Versão reformulada recebida em 19/01/2011

Publicado em 10/06/2011 